\title{
Households, Financial Distress, and Predatory Lending: An Experimental Study
}

\author{
${ }^{1}$ Irwan Trinugroho, ${ }^{2}$ Ariyanto Adhi Nugroho, ${ }^{1}$ Harmadi Harmadi, \\ ${ }^{1}$ Joko Suyono, ${ }^{1}$ Muh Juan Suam Toro \\ ${ }^{1}$ Department of Management Faculty of Economics and Business Universitas Sebelas Maret \\ ${ }^{2}$ Department of Economics Faculty of Economics and Business Universitas Sebelas Maret \\ Jl. Ir. Sutami No.36A Surakarta, 57126, Indonesia
}

\begin{abstract}
Keywords:

Predatory Loan;

Experiment;

Households;

Indonesia

JEL Classification:

D14, G21

A substantial part of households and micro enterprises, particularly in developing countries including Indonesia, did not have access to formal financial institutions which then lead them to borrow money from illegal loan providers. Using an experimental study, we tested whether predatory loan, an illegal short-term loan with high interest rate, was preferable or not by comparing with pawnshop loan, bank loan and household's limited saving when households confront with financial distress. We divided the participants into three groups: lower low, low, and upper low income. We found that predatory loan was preferable especially for lower low and low income group. Result also confirmed that even if the predatory loan charge was increased, the lower low- and low-income groups still prefer to ease their financial distress through predatory loans. Moreover, the longer the duration of the predatory loan, the higher its probability to be chosen as a funding source in times of household financial distress.

ABSTRAK

Kata Kunci:

Rentenir;

Eksperimen; Rumah

Tangga; Indonesia

Sebagian kelompok rumah tangga dan usaha mikro khususnya di negara-negara berkembang termasuk Indonesia tidak memiliki akses ke lembaga-lembaga keuangan formal yang kemudian meminjam uang di pemberi pinjaman yang illegal. Dengan menggunakan metode eksperimen, kami menguji apakah pinjaman rentenir, suatu bentuk pinjaman jangka pendek yang illegal dengan tingkat bunga yang sangat tinggi, lebih dipilih atau tidak dibandingkan dengan pegadaian, pinjaman bank dan tabungan terbatas dari rumah tangga ketika suatu rumah tangga sedang menghadapi kesulitan keuangan. Kami membagi partisipan menjadi 3 grup yaitu pendapatan sangat rendah, rendah, di atas rendah. Kami menemukan bahwa pinjaman rentenir lebih dipilih khususnya oleh kelompok pendapatan sangat rendah dan rendah. Hasil penelitian ini juga mengkonfirmasi bahwa meskipun bunga pinjaman rentenir dinaikkan, kelompok pendapatan sangat rendah dan rendah masih memilih untuk mengatasi kesulitan keuangan dengan pinjaman rentenir. Lebih lanjut, semakin lama durasi dari pinjaman rentenir, semakin tinggi probabilitasnya untuk dipilih sebagai sumber pendanaan ketika ada kesulitan keuangan keluarga.
\end{abstract}

Corresponding Author:

Irwan Trinugroho: Tel.+62 271647 481; Fax.+62 271638143

Email: irwan.trinugroho@gmail.com

ISSN:2443-2687 (Online) ISSN:1410-8089 (Print) 
It has been widely known that a substantial part of households and micro enterprises, particularly in developing countries including Indonesia, does not have access to formal financial institutions which then lead them to borrow money from illegal loan providers which is called predatory lenders (Indonesian: rentenir). Karsidi et al. (2015) analyze the determinants of households' dependency on predatory lenders by conducting a survey in a district in Indonesia. They explain that households' dependency on such loans could be explained from the demand and supply side. On the demand side, low level of financial literacy constrains access of poor people to the formal financial institutions. On the supply side, lending to this part of society is risky and costly for banks.

Predatory lending could be generally defined as a short term credit with limited amount and high charge. This is slightly different with the term "predatory lending" in some papers (e.g. Bond et al., 2009; Agarwal et al., 2014). They argue that predatory lending exists when the lenders encourage borrowers to put mortgages for loans and due to they have private information, the lenders know that borrower does not have enough ability to repay the loans.

However, our predatory lending term here is quite similar with the payday lending that has been regulated in some U.S. states even though it has become a debatable concept. Some papers, both empirical and theoretical, have studied the existence and consequences of payday lending in the US (e.g. Morse, 2011; Bhutta, 2014; Melzer \& Morgan, 2015; Desai \& Elliehausen, 2017).

In this present paper, we examine the preferability of predatory lending in Indonesia for poor households when they encounter financial problem. We construct within and between quasiexperimental design to test whether a predatory loan is preferable over a pawnshop loan, a bank loan, and a household's limited savings. We argue that a pawnshop loan is the direct and bal- anced opponent of a predatory loan. In a pawnshop, people can obtain a loan provided they bring some collateral that matches the amount of funds needed based on the valuation of the pawnshop. We divide the participants into 3 groups, lower low, low, and upper low income. However, we exclude the bank loan option for the lower lowincome group in the experiment because we manipulate this group to reflect a non-bankable or credit-constrained status.

Going deeper we also look at the impact of predatory loan charge (interest) and duration of loan on the preferability of such loan by creating within subject design and by measuring the sensitivity level. Loan charge (interest rate) should be considered to have an impact on how poor people borrow money from predatory lenders even though some might argue that borrowing people are less sensitive to the changing in the charge of this loan. However, as generally argued, we consider that the more the charge on such loans, the less preferable the loan to be chosen. Similarly, we also look at the effect of loan duration on the preferability of predatory loans. Arguably, the longer the duration of loans, the more preferable the loans should be.

Financial deepening and financial inclusion have been a global initiative over the recent decade including in Indonesia. Trinugroho et al. (2015) find that there is a significant disparity in financial deepening across provinces in Indonesia which is resulted from different level of socio-economic development and different level of business environment. It also creates disparity in cost of financial intermediation across regions (Trinugroho \& Wiwoho, 2016). Due to the limited access to banking and other formal financial institutions, a substantial number of poor people particularly in the less developed regions rely on non-formal financial institutions such as predatory lenders. Although this kind of lender is illegal, it exists in many areas in Indonesia both in rural and urban 


\section{Households, Financial Distress, and Predatory Lending: an Experimental Study \\ Irwan Trinugroho, Ariyanto Adhi Nugroho, Harmadi Harmadi, Joko Suyono, Muh Juan Suam Toro}

areas. In many cases, such loans do not require formal collateral due to the lenders create a closer lender-borrower relationship. It is suspected to be an attractive point of this service even though the interest rate is quite expensive.

As explained earlier, the concept of predatory lending in Indonesia closes to the concept of payday lending in the US. The difference is that in the US, some states have regulated it. In the literature, basically, the proponents of the existence of such lending argue that this industry provides financing access to people who have no better alternatives (Caskey, 2002). Morse (2011) explains that in the one side, payday loans help distressed people to overcome liquidity shock, in the opposite side, however, payday loans might encourage people to over consume. Stegman \& Faris (2003) mention that such type of lending is acceptable in the market due to the growing of demand and providers are willing to supply it. Moreover, using data of payday loan industry in North Carolina, they conclude that financial performance of payday loan ind ustry significantly increased. Some other studies (e.g. Stegman, 2007; DeYoung \& Phillips, 2010) argue that the fees that lenders charge for a payday loan should have a ceiling price to reduce the potential predation of this loan.

To our knowledge, limited papers have discussed the role played by predatory lending in the financial intermediary activities in the context of Indonesia. An exception is the paper of Karsidi et al. (2015) that conducting survey to more than 100 households in a region who borrow money from predatory lenders. Basically, they argue that dependency on predatory lending comes from the demand and supply sides. However, the empirical results show that demand side significantly affects the level of dependency.

\section{METHODS}

This study employs an experimental design to examine our hypothesis. In an experiment in the field of economics, participants make a decision in a controlled condition, which is designed to measure the effect of a specific change or treatments on the decision making (Engle-Warnick \& Laszlo, 2008). We construct a quasi-experimental design to capture the decision of the participants with regard to their preferred funding source in some given conditions. We decide to use only male participants because we want to perceive them as heads of households as well as to control the matter of gender difference. A convenience sample of 60 male students, recruited from the Faculty of Economics and Business, a university in Indonesia, was divided randomly into 3 balanced groups, lower low, low and upper low income. We combine within and between subject designs. The within subject design is used to capture the repeated measurements within groups. The between subject design is employed to test difference phenomena between groups. Referring to Charness \& Gneezy (2009), we consider that incentives encourage the participants to seriously take part in the experiment. The detailed procedures of the experiment are shown in Table 1.

\section{RESULTS}

Table 2 shows the results of the baseline measurement. In a given set of conditions, the participants in each group choose their preferred funding for an unexpected expense. We compare the percentage difference in predatory loans between the 3 groups. The lower low-income group has a higher predatory loan percentage than the other groups. Its average predatory loan percentage is 50.83 . This means that 50.83 percent of their needed fund would be obtained from predatory lending. The predatory loans percentage of low and upper low-income are 41.5 and 32.5, respectively. The F-test result shows that the predatory loan percentages are not significantly different between groups. In all the groups, the predatory loan is the most preferred funding source. 


\section{Jurnal Keuangan dan Perbankan | PERBANKAN}

Vol. 21, No. 3, Juli 2017: 473-480

Table 3 shows the results of treatments 1 and 2 . In these treatments, the charge or fee for a predatory loan is increased to 15 percent and 20 percent. Elasticity of predatory loan charge is measured using this formula: \% change of average \% predatory loan divided by $\%$ change of predatory loan charge. Figure I illustrates the predatory loan charge elasticity. The within subject design compares the differences preferred funding before and after treatments 1 and 2 . The F-tests for lower low and low-income groups indicate that there is no significant difference in the predatory loan percentage before and after the 2 treatments, however there is significant difference in the upper lowincome group. The result confirms that even if the predatory loan charge is increased to 20 percent, the lower low and low-income groups still prefer to ease their financial distress through predatory loans.

Table 4 presents the results of treatments 3 and 4 . In these treatments, the duration of the

Table 1. Design of Experiment

\begin{tabular}{|c|c|}
\hline Step & Description \\
\hline 1 & $\begin{array}{l}\text { Constructing the conditions reflecting the three groups: lower low-income, low-income and upper low- } \\
\text { income. We divide the participants into these three groups due to our focus here is on poor households. } \\
\text { - Lower low-income: The participants in this group are characterized as heads of households with income } \\
600,000 \text { Rupiah per month (1 USD is currently equal to 13,300 Indonesian Rupiah). They have } 1 \text { million } \\
\text { Rupiah in their saving account. There is an unexpected expense of } 600,000 \text { Rupiah that have to be paid in } \\
\text { two days. They have a television which can be collateral of pawnshop loan. They have three options to pay } \\
\text { the unexpected expense: use their saving account, borrow in predatory lender or borrow from pawnshop. } \\
\text { Low-income: The participants in this group are characterized as heads of households with income } 1 \text { million } \\
\text { Rupiah per month. They have } 2 \text { million Rupiah in their saving account. There is an unexpected expense of } \\
1 \text { million Rupiah that have to be paid in two days. They have a television and an ownership certificate of } \\
\text { motorcycle which can be collateral of pawnshop loan. They have four options to pay the unexpected } \\
\text { expense: use their saving account, borrow in predatory lender, borrow in pawnshop or borrow in bank. } \\
\text { Upper low-income: The participants in this group are characterized as a head of households with income } \\
\text { 1.5 million Rupiah per month. They have } 3 \text { million Rupiah in their saving account. There is an unexpected } \\
\text { expense of } 1.5 \text { million Rupiah that have to be paid in two days. They have a television, an ownership } \\
\text { certificate of motorcycle and a motorcycle which can be collateral of pawnshop loan. They have four } \\
\text { options to pay the unexpected expense: use their saving account, borrow in predatory lender, borrow in } \\
\text { pawnshop or borrow in bank. }\end{array}$ \\
\hline 2 & $\begin{array}{l}\text { Constructing the baseline characteristics of the three funding options: predatory loan, pawn-shop loan and } \\
\text { bank loan. } \\
\text { - Predatory loan: The amount of the loan is } 200,000-2 \text { million Rupiah. The duration of the loan is } 2 \text { week. } \\
\text { The charge for the loan is } 10 \% \text { which is equal to } 20 \% \text { per month. } \\
\text { - Pawnshop loan: The maximum loan is } 3 \text { million Rupiah. The maximum duration is } 36 \text { month. Interest rate } \\
\text { is } 1 \% \text { per month. } \\
\text { - Bank loan: The annual interest rate is } 13 \% \text {. The minimum loan is } 1 \text { million Rupiah. }\end{array}$ \\
\hline 3 & Measuring baseline: The participants choose what kind and how much their preferred funding source. \\
\hline 4 & $\begin{array}{l}\text { Measuring the predatory loan charge sensitivity (elasticity) } \\
\text { - } \quad \text { Treatment } 1\left(\mathrm{~T}_{1}\right) \text { : The predatory loan charge is increased to } 15 \% \\
\text { - } \quad \text { Treatment } 2\left(\mathrm{~T}_{2}\right) \text { : The predatory loan charge is increased to } 20 \%\end{array}$ \\
\hline 5 & $\begin{array}{l}\text { Measuring the predatory loan duration sensitivity (elasticity) } \\
\text { - Treatment } 3\left(\mathrm{~T}_{3}\right) \text { : The predatory loan duration is extended to } 3 \text { weeks } \\
\text { - } \quad \text { Treatment } 4\left(\mathrm{~T}_{4}\right) \text { : The predatory loan duration is extended to } 4 \text { weeks }\end{array}$ \\
\hline
\end{tabular}




\section{Households, Financial Distress, and Predatory Lending: an Experimental Study \\ Irwan Trinugroho, Ariyanto Adhi Nugroho, Harmadi Harmadi, Joko Suyono, Muh Juan Suam Toro}

predatory loan is extended to 3 weeks and 4 weeks, respectively. Figure II presents the predatory loan duration elasticity. Elasticity of preda- tory loan duration is measured using this formula: $\%$ change of average $\%$ predatory loan divided by $\%$ change of predatory loan duration.

Table 2. Result of Baseline Measurement

This table presents the results of the baseline measurement. The participants choose the source of funding for their unexpected expense in the baseline characteristics of the predatory loan. The lower low-income group does not have access to bank loan. The value in this table is percentage of fund. The between subject design compares the percentage of preferred funding between three groups. ${ }^{*}, * *$, and ${ }^{* * *}$ indicate significance of difference at the 10 percent, 5 percent, and 1 percent levels, respectively.

\begin{tabular}{lrrrrrr}
\hline \multicolumn{1}{c}{ Group } & \multicolumn{2}{c}{ Predatory Loan } & \multicolumn{2}{c}{ Pawnshop Loan } & \multicolumn{2}{c}{ Bank Loan } \\
\hline & \multicolumn{1}{c}{ Mean } & \multicolumn{1}{c}{ St.Dev } & Mean & St.Dev & Mean & St.Dev \\
\hline Lower Low Income & 50.83 & 39.17 & 25 & 35.25 & X & X \\
Low Income & 41.5 & 39.51 & 20.5 & 30.51 & 10 & 30.78 \\
Upper Low Income & 32.5 & 38.42 & 15 & 26.98 & 30 & 43.12 \\
F-value for mean difference test & $\mathbf{1 . 1 0 3}$ & & $\mathbf{0 . 5 1 9}$ & & $\mathbf{2 . 8 5 *}$ \\
\hline
\end{tabular}

Table 3. Result of Predatory Loan Charge Sensitivity This table presents the result of the treatments 1 and 2 . In these treatments, the charge or fee of predatory loan is increased to 15 percent and 20 percent. The lower low-income group does not have access to bank loan. The within subject design compares the percentage of preferred funding within group before and after treatments. *,**, and ${ }^{* * *}$ indicate significance of difference at the 10 percent, 5 percent, and 1 percent levels, respectively.

\begin{tabular}{|c|c|c|c|c|c|c|}
\hline & \multicolumn{2}{|c|}{ Predatory Loan } & \multicolumn{2}{|c|}{ Pawnshop Loan } & \multicolumn{2}{|c|}{ Bank Loan } \\
\hline & Mean & St.Dev & Mean & St.Dev & Mean & St.Dev \\
\hline \multicolumn{7}{|l|}{ Group 1: Lower Low Income } \\
\hline Baseline & 50.83 & 39.17 & 25 & 35.25 & $X$ & $\mathrm{X}$ \\
\hline Treatment 1 & 45 & 43.29 & 23.33 & 33.51 & $X$ & $X$ \\
\hline Treatment 2 & 39.17 & 40.56 & 25.83 & 33.54 & $X$ & $X$ \\
\hline F-value for mean difference test & 0.429 & & 0.028 & & & \\
\hline \multicolumn{7}{|l|}{ Group 2: Low Income } \\
\hline Baseline & 41.5 & 39.51 & 20.5 & 30.51 & 10 & 30.78 \\
\hline Treatment 1 & 32.5 & 33.69 & 23.5 & 31.33 & 10 & 30.78 \\
\hline Treatment 2 & 25.5 & 34.86 & 23 & 34.81 & 15 & 36.63 \\
\hline F-value for mean difference test & 0.987 & & 0.05 & & 0.154 & \\
\hline \multicolumn{7}{|l|}{ Group 3: Upper Low Income } \\
\hline Baseline & 32.5 & 38.42 & 15 & 26.98 & 30 & 43.12 \\
\hline Treatment 1 & 15.83 & 26.2 & 16.67 & 29.12 & 35 & 45.21 \\
\hline Treatment 2 & 9.17 & 16.64 & 18.33 & 29.07 & 38.33 & 44.95 \\
\hline F-value for mean difference test & $3.55^{* *}$ & & 0.069 & & 0.178 & \\
\hline
\end{tabular}


The within subject design compares the differences preferred funding before and after treatments 3 and 4 . The F-tests show that the predatory loan percentage before and after the two treatments is significantly different in the lower low-income group but not significant in the low and upper low-income groups. The results indicate that the duration of the predatory loan is an important factor in deciding to obtain a predatory loan to ease financial distress. The longer the duration of the predatory loan, the higher its probability to be chosen as a funding source in times of

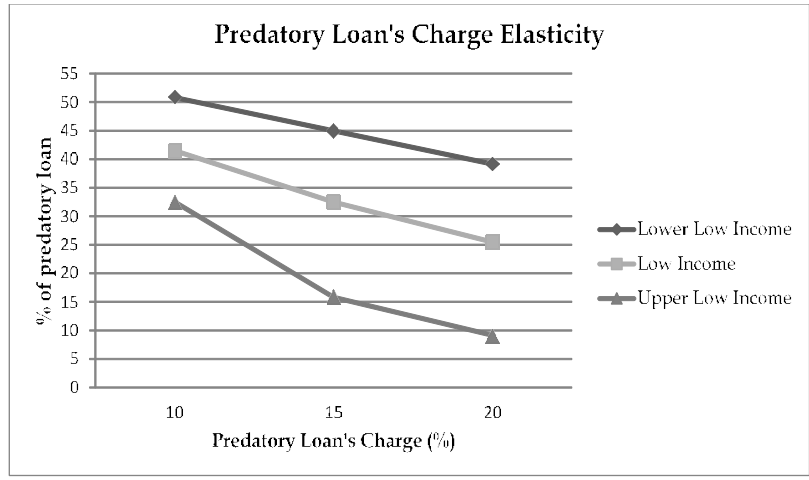

Figure 1. Predatory Loan's Charge Elasticity individual financial distress.

Table 4. Result of Predatory Loan Duration Sensitivity

This table presents the results of the treatments 3 and 4 . In these treatments, the duration of predatory loan is longer to 3 weeks and 4 weeks. The lower low-income group does not have access to bank loan. The within subject design compares the percentage of preferred funding within group before and after treatments. ${ }^{*}, * *$, and $* * *$ indicate significance of difference at the 10 percent, 5 percent, and 1 percent levels, respectively.

\begin{tabular}{|c|c|c|c|c|c|c|}
\hline & \multicolumn{2}{|c|}{ Predatory Loan } & \multicolumn{2}{|c|}{ Pawnshop Loan } & \multicolumn{2}{|c|}{ Bank Loan } \\
\hline & Mean & St.Dev & Mean & St.Dev & Mean & St.Dev \\
\hline \multicolumn{7}{|l|}{ Group 1: Lower Low-Income } \\
\hline Baseline & 50.83 & 39.17 & 25 & 35.25 & $X$ & $x$ \\
\hline Treatment 3 & 58.33 & 36.47 & 20.83 & 31.47 & $X$ & $\mathrm{X}$ \\
\hline Treatment 4 & 75 & 29.37 & 10.83 & 25.52 & $X$ & $\mathrm{X}$ \\
\hline F-value for mean difference test & $2.46^{*}$ & & 1.103 & & & \\
\hline \multicolumn{7}{|l|}{ Group 2: Low-Income } \\
\hline Baseline & 41.5 & 39.51 & 20.5 & 30.51 & 10 & 30.78 \\
\hline Treatment 3 & 49 & 42.04 & 15.5 & 29.28 & 10 & 30.78 \\
\hline Treatment 4 & 60.5 & 41.61 & 10 & 26.16 & 10 & 30.78 \\
\hline F-value for mean difference test & 1.086 & & 0.669 & & 0.000 & \\
\hline \multicolumn{7}{|l|}{ Group 3: Upper Low-Income } \\
\hline Baseline & 32.5 & 38.42 & 15 & 26.98 & 30 & 43.12 \\
\hline Treatment 3 & 39.17 & 40.92 & 13.33 & 26.82 & 26.67 & 42.71 \\
\hline Treatment 4 & 48.33 & 42.2 & 9.17 & 25.06 & 25 & 40.28 \\
\hline F-value for mean difference test & 0.769 & & 0.261 & & 0.073 & \\
\hline
\end{tabular}




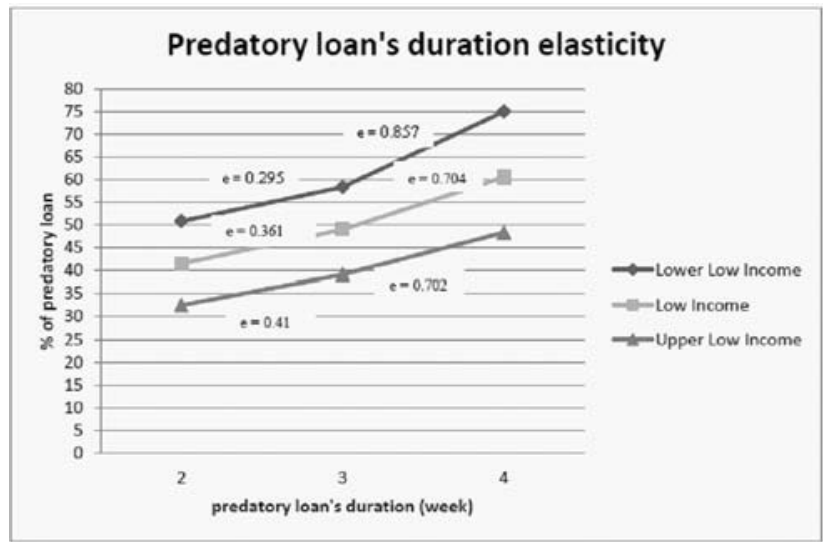

Figure 2. Predatory Loan's Duration Elasticity

\section{DISCUSSION}

Our study clearly shows that predatory loan is the main alternative of financing especially for lower-low income households when they face unexpected expense. The preferability of predatory lending shown in our experimental study implies that predatory lending is a main source of funding for credit-constrained households to mitigate their financial distress. It is consistent with the finding of Morse (2011), Gallmeyer \& Roberts (2009), and Karsidi et al. (2015) in which financially distressed households would prefer to borrow money from this lender to overcome financial shock even though the interest rate is quite high.

\section{CONCLUSION AND SUGGESTIONS}

\section{Conclusion}

Our experimental study obviously shows that the predatory lending is preferable especially for the lower low and low-income households when unexpected expense create financial distress to those households. It implies that regulator, in the framework of financial inclusion, should mitigate this problem. Extending the access to formal financial instructions for poor households should be bolstered and diversified. Digital financial ser- vices could be a tool for financial inclusion (Trinugroho et al., 2017), however, it strongly needs improved infrastructure and the level of financial literacy should also be accelerated. Moreover, bolstering the role of Islamic banks to reach the poor people is also strongly expected (Risfandy et al., 2016).

\section{Suggestions}

With regards to the future studies in this particular field, we suggest some directions. First, it is suggested to test the preferability of predatory loan on real households by using different methods that are survey method and employing secondary data. Extending the category of predatory loan market by including micro enterprises to prove that predatory lending is also used for productive economic activities would be an interesting as well.

\section{REFERENCES}

Agarwal, S., Amromin, G., Ben-David, I., Chomsisengphet, S., \& Evanoff, D.D. 2014. Predatory Lending and the Subprime Crisis. Journal of Financial Economics, 113(1): 29-52.

Bhutta, N. 2014. Payday Loans and Consumer Financial Health. Journal of Banking \& Finance, 47: 230-242.

Bond, P., Musto, D.K., \& Yilmaz, B. 2009. Predatory Mortgage Lending. Journal of Financial Economics, 94(8): 412-427.

Caskey, J.P. 2002. The Economics of Payday Lending. Wisconsin: Filene Research Institute.

Charness, G. \& Gneezy, U. 2009. Incentives to Exercise. Journal of the Econometric Society, 77(3): 909-931.

Desai, C.A. \& Elliehausen, G. 2017. The Effect of State Bans of Payday Lending on Consumer Credit Delinquencies. The Quarterly Review of Economics and Finance, 64(C): 94-107.

DeYoung, R. \& Phillips, R.J. 2010. Payday Loan Pricing. Working Paper. Available at http:// $\mathrm{p}$ a p e r s.s s r . c o m / s o $13 /$ papers.cfm?abstract_id=1066761. 


\section{Jurnal Keuangan dan Perbankan | PERBANKAN}

Vol. 21, No. 3, Juli 2017: 473-480

Engle-Warnick, J. \& Laszlo, S. 2008. Experimental Economics: A Revolution in Understanding Behavior. Montreal: Center for Inter University Research and Analysis on Organizations (CIRANO) McGill University.

Gallmeyer, A. \& Roberts, W.T. 2009. Payday Lenders and Economically Distressed Communities: A Spatial Analysis of ûnancial Predation. The Social Science Journal, 46(3): 521-538.

Karsidi, R., Trinugroho, I., Nugroho, L.I., Prabowo, A. 2015. Why Households Borrow from Informal Predatory Lenders: Evidence from Indonesia. Journal of Economics and Economic Education Research, 16(2): 173-185.

Melzer, B.T. \& Morgan, D.P. 2015. Competition in A Consumer Loan Market: Payday Loans and Overdraft Credit. Journal of Financial Intermediation, 24(1): 2544.

Morse, A. 2011. Payday Lenders: Heroes or Villains? Journal of Financial Economics, 102(1): 28-44.
Risfandy, T., Husa, P.P., \& Asrihapsari, A. 2016. Daya Saing Bank Syariah di Sebuah Negara Religius: Temuan Empirik dari Indonesia. Jurnal Keuangan dan Perbankan, 20(2): 282-291.

Stegman, M.A. 2007. Payday Lending. Journal of Economic Perspectives, 21(1): 169-190.

Stegman, M.A. \& Faris, R. 2003. Payday Lending: A Business Model that Encourages Chronic Borrowing. Economic Development Quarterly, 17(1): 8-32.

Trinugroho, I., Agusman, A., Ariefianto, M.D., Darsono, D., \& Tarazi, A., 2015. Determinants of Cross Regional Disparity in Financial Deepening: Evidence from Indonesian Provinces. Economics Bulletin, 35(2): 896-910.

Trinugroho, I. \& Wiwoho, J. 2016. Local Institutional Development and Cost of Financial Intermediation: Evidence from Indonesia. International Journal of Business, 21(4): 319-327.

Trinugroho, I., Sawitri, H.S.R., Toro, M.J.S, Khoiriyah, S., \& Santoso, A.B. 2017. How Ready are People for Cashless Society. Jurnal Keuangan dan Perbankan, 21(1): 105-112. 